\title{
PERFORMANCE AUDIT: A TOOL FOR FIGHTING CORRUPTION IN THE NIGERIA'S PUBLIC SECTOR ADMINISTRATION
}

\author{
Sunny Agbo' ${ }^{1}$--- Jude A. Aruomoaghe ${ }^{2}$ \\ ${ }^{1,2}$ Department of Accounting, College of Business $\Theta^{2}$ Management Studies, Igbinedion University, Okada Edo State, \\ Nigeria
}

\begin{abstract}
The efficient and effective management of financial resources forms the basis for achieving good governance. In achieving the good governance, fiscal transparency and accountability must be ensured. Performance audit provides the platform to determine if the resources are being managed with due regard for economy, efficiency and effectiveness and that accountability requirements are being met reasonably. This study looks at performance audit as a tool for fighting corruption in Nigerian public sector administration. Questionnaires were distributed and analysed using the Pearson's correlation co-efficient and we discovered that performance audit could be an effective tool in curbing corruption. It was suggested that performance audit report should be made public and stringent punishment should be melted on offenders to serve as deterrent to others.
\end{abstract}

Keywords: Corruption, Nigeria, Performance audit, Public sector, Administration, Governance.

Received: 29 January 2014/ Revised: 22 March 2014/ Accepted: 8 April 2014/ Published: 23 April 2014

\section{INTRODUCTION}

Governance refers to the manner in which public officials and Institutions acquire and exercise authority to shape public policy and provide goods and services, which will enhance the welfare of the public. Dereje (2012) defines governance as the norms, traditions, and institutions by which power and authority in a country are exercised. The mobilization and utilization of financial resources for the public good is an essential part of governance. In countries with "good governance" citizens respect the government because among other reasons those in authority manage public resources effectively. Where governance systems are not working effectively or transparency and accountability mechanisms are weak, corruption and mismanagement of public 
resources often increases. One predictable outcome under these circumstances is that the public needs are marginalized and development outcomes suffer.

In Nigeria today, highly placed government functionaries do not see any need for judiciously expending public funds, thus erroneously believing that it is their own share of the national cake (Oladipupo, 2005). Corruption has lowered the quality of services, reduced revenue, encourage redirection and misappropriation of public fund, and the public are left to suffer after they have contributed to revenue by paying taxes, fines, fees etc. These actions by politicians and public office holders have called the attention of many Professionals to determine ways whereby these public office holders are accountable to the citizens in other to enhance the economical, efficient and effective use of public resources. One of such ways is through performance audit.

This paper therefore looks at performance audit as a tool for fighting corruption in Nigeria's public sector administration. The remaining part of the paper is divided into; literature review, methodology and conclusion.

\section{LITERATURE REVIEW}

According to ASOSAI (2003), Performance audit may be defined as examining, whether Government Ministries are doing "the right thing" and doing this in "the right and least expensive way". Khan (2006) on his part sees Performance auditing as an assessment of the activities of an organization to see if the resources are being managed with due regard for economy, efficiency and effectiveness and accountability requirements are being met reasonably. (INTOSAI) sees Performance auditing as a way for taxpayers, financiers, legislatures, executives, ordinary citizens and the media to 'execute control' and to obtain insight into the running and outcome of different government activities. Performance audit is therefore an essential element for the accountability process in all public-jurisdiction.

The process of performance audit may differ. In Megbeluba (2010), it was stated that the process of performance audit is made up of economy, efficiency and program audits. Economy and efficiency audits determine whether the entity is following sound procurement practice; acquiring appropriate types of resources; properly protecting and maintaining resources; avoiding duplication of effort by employees; avoiding idleness and overstaffing; using efficient operating procedures; using optimum amounts of resources; complying with requirements of laws and regulations that could affect acquisition, protection, and use of resources; has an adequate management control system. Program audit on the other hand may assess whether the objectives of a program is achieving its goals; identify factors inhibiting satisfactory performance; identify ways of making programs work better; and determine whether management has reported measures of program effectiveness that are valid and reliable (Megbeluba, 2010).

Khan and Chowdry (2008) are of the opinion that the process of performance audit involves,

1. Determining the value of the projects executed by each ministry/extra ministerial department in relation to the money spent on them. 
2. Ensuring that whatever money spent on the implementation of projects and provision to the members of the public commensurate with the value of such projects.

3. Ascertaining the compliance of the ministries to government appropriation bill and budget.

4. Determine exactly what was done and what values members of the public have derived from them.

\subsection{Differences between Traditional Auditing and Performance Auditing}

Performance auditing differs in many ways from financial Statement auditing. According to Oladipupo (2005) the differences are as follows:

1. Traditional auditing uses financial data only to express an opinion on financial position and compliance with rules and regulations while performance auditing uses financial as well as nonfinancial data to assess economy, efficiency and effectiveness in management of resources.

2. Traditional auditing focuses on transactions pointing out errors, omission, frauds and impropriety while performance auditing focuses on overall performance of an organization programmes or project but remains alert to any errors, omission or frauds.

3. Traditional auditing does not comment on the extent to which government departments are meeting the expectation of the target groups they are serving while performance auditing evaluates the extent to which government departments are meeting the expectations of target groups.

4. Traditional auditing does not make recommendations for improving economy, efficiency and effectiveness of the government departments while performance auditing makes general recommendations for improving economy, efficiency and effectiveness of government departments.

\subsection{Performance Audit and Corruption}

Lipset and Lenz (2000) see corruption as efforts to secure wealth or power through illegal means - private gain at public expense; or a misuse of public power for private benefit. While Tanzi (1998) on his part defines corruption as the intentional noncompliance with arm's length relationship aimed at deriving some advantage from this behavior for oneself or for related individuals.According to Sundgren (2009) Corruption has economic and social consequences; it reduces revenues for the state and lowers the quality of public services. Corruption slows GDP growth and adversely affects capital accumulation. It lowers the quality of education, public infrastructure and health services; it reduces the effectiveness of development aid and increases income inequality and poverty. Corruption can be seen as a function and the degree of corruption depends on the relationship between different factors:

$$
\text { Corruption }=\frac{\text { complication in decision } \times \text { waiting times }}{\text { control } \times \text { consequences }}
$$

Source: Sundgren (2009) 
The risk for corruption is a function of the amount of control and the degree of consequences if the corrupt civil servant is caught. It is also a function of the complication in the decision making process and the amount of time to get the service without a bribe.

From the above it is evident that the more complicated decision processes and the longer waiting times the larger risk for corruption. The lesser control and risk to be caught and if, even when caught, there is no or only minor consequences the larger the risk for corruption.

Performance auditing when properly carried out can help reduce corruption. This will occur when then performance audit is properly planned in such a way to highlight the areas that are likely to be prone to corruptive tendencies in the execution of the project. For this purpose, the performance auditors need to go a step deeper into the issues identified during the audit planning stage (Khan, 2006).

In Otalor and Eiya (2013), it is stated that if the findings of the performance audit were of the following nature, the suspicion that corruption had taken place in these projects or programs would be quite high;

(a) Corruption indicated by lack of economy: Cost overruns have taken place as a result of subsequent increase in the scope of work which has not been approved by the competent authority; The accountability mechanism for exceeding the budget is weak suggesting that if a program manager exceeds his or her budget, he or she can get away with it, without much accountability; The unit cost of some components of the total procurement is exorbitant, while the overall bid price is the lowest, the components with higher prices are subject of repeat orders; Bids for competitive procurement may be cancelled frequently to help a specific vendor get the award of the contract; After competitive bidding, the prices are increased by adding some small segments of goods and services not originally conceived; Procurement is rushed at the year-end to consume the budget; In case of privatization, the friends, relations or front men of persons making the decision of privatization purchase the public asset indicating that obvious conflict of interest exists; The options analysis for justifying the project or program was based on fake data or false assumptions; Based on bogus assumptions, the decision to provide in-house services as compared to outsourcing through competitive bidding may be with the intention of having access to a greater chunk of the budget and thus creating opportunity for the staff to indulge in corruption and misappropriation; Large known dealers in certain line of products systematically avoid participating in the open bidding process of the organization. Usually, they do not like to get into the 'hassle' of getting their invoices paid in a corrupt environment (Otalor and Eiya, 2013).

(b) Corruption indicated by lack of efficiency. This consists of: Huge idle capacity or unnecessary equipment purchased without significant possibilities of use even over time; disproportionately high expenditure on maintenance soon after the completion of the project; neglect of regular maintenance thus allowing infrastructure to deteriorate while new projects are being planned. (The intention of neglecting routine maintenance is to divert funds toward new 
projects); Poor quality of construction, shoddy materials, choked gutters, clogged drains, piling of waste material and rubbish around construction sites are indicators of corruption; Abnormal timeover run (over and above a reasonable figure adopted as audit criteria) accepted and regularized by the management as 'beyond control'; Repeated extensions are given to the contractors; Repeated change orders are issued leading to changes in the scope of work and prices to be paid or changes made in the quality of the goods and services to be delivered. Repeated transfers of the project staff are made to ensure complete absence of institutional memory or continuity of oversight within the organization; Liquidated damages clause in the contract defined in such a manner that it does not have a bite; An over-load of controls, or existence of complicated procedures leading to delay in delivery of service and inducing the clients to offer bribes; Absence of any service delivery benchmarks and excessive time taken for issuing licenses and permits, encouraging payment of speed money (Rose-Ackermam, 1999).

(c) Corruption indicated by lack of effectiveness takes the form of: Well-articulated, measurable or quantified performance indicators do not exist; Actual internal rate of return (IRR) is significantly lower than anticipated; Perceived clients' dissatisfaction with the delivery of services. Surveys have revealed that outputs and services are not delivered as planned or quality is seriously undermined, there are barriers to reach the senior management for protesting against poor quality of service and there is no other complaint handling mechanism to address the complaints of the unsatisfied users of services (Otalor and Eiya, 2013).

The performance auditing can help minimize corruption by creating deterrent. According to Otalor and Eiya (2013), the following are some good practices the public sector auditor can adopt:

(a) The top management or governing body should encourage performance auditing over routine compliance auditing.

(b) The top management should inform all program managers that their performance would be audited. All programs and projects should be subjected to performance audit periodically.

(c) The top management should support the performance auditors in developing mutually acceptable performance audit criteria and all managers should be aware of the criteria.

(d) The top management should also prescribe in detail the mechanism for accumulating data and other information on performance of the program at the levels of individual manager, unit or section. The performance auditors should take these data as assertions of the management about their performance and verify these assertions during their audit work

\subsection{Benefits of Performance Audit}

Performance audit can be of great benefit to the public sector. In Oladipupo (2005), the stated benefits include,

1. Informs the management and public at large whether value for money is being received from the public expenditure. 
2. Informs the 'authority' whether generally accepted management practices are being followed in government organization.

3. Demonstrate general direction for improvement.

4. It source of independent and reliable information for the legislation and top management.

5. Sharpens the process of accountability in public administration

6. Provides fresh ideas to public managers. It creates awareness among public managers toward efficiency and effectiveness.

\section{METHODOLOGY}

In this study, the primary data were used for analysis. Questionnaires were constructed and distributed to Government Ministries and Local Government Councils in Edo and Delta states of Nigeria. To aid our data analysis, we constructed two hypotheses.

$\boldsymbol{H o}_{\mathbf{1}}$ : There is no significant relationship between performance audit and the reduction of corruption in the public sectors in Nigeria.

$\boldsymbol{H o}_{2}$ : Performance Audit has no relationship with Financial and Managerial Performance of public sector Administration.

A total one hundred (100) questionnaires were distributed to staff of these various Ministries and Local Government Councils out of which Ninety-four (94) were properly filled and returned. The analysis of the returned questionnaires is given below:

Table-1. Analysis of Questionnaires Distributed and Returned.

\begin{tabular}{lcc}
\hline Questionnaires & Number of Respondents & Percentage (\%) \\
\hline Filled and Returned & 94 & $94 \%$ \\
\hline Not Returned & 6 & $6 \%$ \\
\hline Total & 100 & $100 \%$ \\
\hline
\end{tabular}

Source: Field work, 2013.

In testing for the hypotheses, the correlation co-efficient was used. The result for hypothesis one is presented below:

Table-2. Correlations between Performance Audit and Corruption Reduction.

\begin{tabular}{llll}
\hline Correlation & & Performance & Reduction \\
\hline \multirow{2}{*}{$\begin{array}{l}\text { Performance } \\
\text { Audit }\end{array}$} & Pearson Correlation & 1 & $.890^{* *}$ \\
\cline { 2 - 4 } & Sig. (2-tailed) & .000 \\
\cline { 2 - 4 } & $\mathrm{N}$ & 94 & 94 \\
\hline $\begin{array}{l}\text { Reduction of } \\
\text { Corruption }\end{array}$ & Pearson Correlation & $.890^{* *}$ & 1 \\
\cline { 2 - 4 } & Sig. (2-tailed) & .000 & 94 \\
\hline
\end{tabular}

**. Correlation is significant at the 0.01 level (2-tailed).

Source: SPSS Output 
Decision Rule: When co-efficient is positive and tend towards one, reject $\mathrm{H}_{\mathrm{o}}$ and accept $\mathrm{H}_{1}$ and when co-efficient is negative, accept $\mathrm{Ho}$ and reject $\mathrm{H}_{1}$. The result shows that there is a significant correlation between the performance audit and reduction in corruption at a significant level of 0.01 or $1 \%$. Also the significance can be seen from the result, as the coefficient is a positive 0.890 or $89 \%$. The decision to be taken therefore is to reject the null and accept the alternate hypothesis.

The result for hypothesis two is also given below:

Table-3. Correlations between Performance Audit and financial Managerial performance

\begin{tabular}{|c|c|c|c|}
\hline Correlation & & Performance & Managerial \\
\hline \multirow{3}{*}{$\begin{array}{l}\text { Performance } \\
\text { Audit }\end{array}$} & Pearson Correlation & 1 & $.821^{* *}$ \\
\hline & Sig. (2-tailed) & & .000 \\
\hline & $\mathrm{N}$ & 94 & 86 \\
\hline \multirow{3}{*}{$\begin{array}{l}\quad \text { Financial } \\
\text { Managerial } \\
\text { Performance }\end{array}$} & Pearson Correlation & $.821^{* *}$ & 1 \\
\hline & Sig. (2-tailed) & .000 & \\
\hline & $\mathrm{N}$ & 86 & 86 \\
\hline
\end{tabular}

**. Correlation is significant at the 0.01 level (2-tailed).

Source: SPSS Output

The result shows that there is a significant relationship between Performance Audit and Managerial Performance. Also the significance can be seen from the result, as the coefficient is positive at 0.821 or $82 \%$. The decision to be taken therefore is to reject the null hypothesis and accept the alternate hypothesis

From the data analysed above, we can summarize our findings thus:

1. There is a significant relationship between performance audit and the reduction of corruption in the public sectors in Nigeria.

2. Performance Audit has a relationship with Financial and Managerial Performance of public sector Administration.

\section{CONCLUSION AND RECOMMENDATIONS}

Performance audit seems to be a remedy for corruption because it creates an unfavourable environment for it to rapidly occur and closes loopholes for corruption to thrive. Corruption requires a multifaceted attack and Performance Audit is only one of such mechanism. The time has come for proper decision making, proper utilization of resources, transparency and accountability of the taxpayers money.

Performance audit is a means to an end because it points out opportunities of corruption and waste, thereby ensuring that such opportunities are not utilized but rather the resources are used appropriately. Based on the above, the following recommendations may be necessary, 
1. Performance audit should be made a mandatory requirement in the public sectors over routine compliance audit.

2. Performance audit report should be published so that transparency and accountability will be highly achieved.

3. There should be stringent punishment for offenders to serve as deterrent to others.

4. The professional bodies in Nigeria (e.g ICAN \& ANAN) should organise necessary training programme on performance audit to their members in practice.

5. The management of State, Federal and various Local Government Councils should aid the auditors by introducing in their territory strict Internal checks and efficient audit, motivation of Government officials, mapping out adequate reward for detecting fraud and regular training of staff.

Funding: This study received no specific financial support.

Competing Interests: The authors declare that they have no competing interests.

Contributors/Acknowledgement: All authors contributed equally to the conception and design of the study.

\section{REFERENCES}

ASOSAI, 2003. Asian organization of supreme audit Institution guidelines Asia. Available from www. asosai.org [Accessed $7^{\text {th }}$ July 2013].

Dereje, T., 2012. Role of performance audit in fighting corruption: Evidences from FDRE and Oromia National Regional State. A Thesis Submitted to Department of Accounting and Finance, Addis Ababa University Ethiopia.

INTOSAI, The international sandards of supreme audit institutions, performance audit guidelines: ISSAI $3000-3100$. Available from www.intosai.org [Accessed $7^{\text {th }}$ July 2013]

Khan, M., 2006. The role of audit in the fight against corruption. Being a paper prepared for Ad Hoc group meeting on ethics, integrity, and accountability in the public sector: Re-building Public Trust in Government through the Implementation of the UN Convention against Corruption. 26-27 September 2006. St. Petersburg, Russia.

Khan, M. and N. Chowdry, 2008. Public accountability in differencing governance situations: Challenges and options. Asian pacific Journal of Administration, 30(1): 15 - 28.

Lipset, S.M. and G.L. Lenz, 2000. Corruption, culture, and markets, in culture matters. Lawrence E. Harrison, and Samuel P. Huntington, eds. New York: Basic Books. pp: 112.

Megbeluba, A., 2010. Performance audit in Nigeria. A seminar paper presented at Igbinedion University, Okada on 2nd December, 2010. pp: 1-15.

Oladipupo, A.O., 2005. Auditing and investigation: Theory and practice. Benin City, Nigeria: Mindex Publishers.

Otalor, J.I. and O. Eiya, 2013. Combating corruption in Nigeria: The role of the public sector auditor research. Journal of Finance and Accounting, 4(4): 122-131.

Rose-Ackermam, S., 1999. Corruption and government: Causes, consequences, and reform. Cambridge: Cambridge University Press, pp: 30-31. 
Sundgren, B., 2009. Corruption and the role of financial and performance audit. AFROSAI- $\quad$ E $\quad$ activities within PA. (AFROSAI-E Performance Audit Manager). Available from www.afrosai-e.org [Accessed 10 $0^{\text {th }}$ february 2010]. Tanzi, V., 1998. Corruption around the world: Causes, consequences, scope, and cures. IMF Working Paper: 1-39. Available from http://ssrn.com [Accessed 10th February, 2010].

\section{APPENDIX}

\section{QUESTIONS AND RESPONSE FROM RESPONDENTS}

Question: Is there any significant relationship between performance audit and the reduction of corruption?

Table-1. Relationship between Performance Audit and Reduction of Corruption.

\begin{tabular}{|c|c|c|c|c|}
\hline Options & Frequency & Percent & Valid Percent & Cumulative Percent \\
\hline Yes & 82 & 87.2 & 87.2 & 87.2 \\
\hline No & 12 & 12.8 & 12.8 & 100.0 \\
\hline Tota & 94 & 100.0 & 100.0 & \\
\hline
\end{tabular}

Source: field survey 2013

Question: To what Extent has Performance Audit Improved the Financial and Managerial Performance of the Council?

Table-11. The Extent to which performance Audit has improved Financial and Managerial Performance of the Council.

\begin{tabular}{|c|c|c|c|c|c|}
\hline \multirow[t]{2}{*}{ Options } & \multirow[b]{2}{*}{ Frequency } & \multicolumn{3}{|c|}{ Percen } & \multirow{2}{*}{$\begin{array}{l}\text { Cumulative } \\
\text { Percent }\end{array}$} \\
\hline & & $\mathbf{t}$ & & Valid Percent & \\
\hline Great Extent & 80 & & 85.1 & 93.0 & 93.0 \\
\hline No Extent & 6 & & 6.4 & 7.0 & 100.0 \\
\hline Total & 86 & & 91.5 & 100.0 & \\
\hline Missing & 8 & & 8.5 & & \\
\hline Total & 94 & & 100.0 & & \\
\hline
\end{tabular}

Source: field survey 2013

\section{SPSS OUTPUT RESULTS}

\section{HYPOTHESIS ONE}

\section{NONPAR CORR}

/VARIABLES=Performance Reduction

/PRINT=SPEARMAN TWOTAIL NOSIG

$/$ MISSING=PAIRWISE. 


\section{Descriptive Statistics}

\begin{tabular}{llll}
\hline & Mean & Std. Deviation & N \\
\hline Performance & 1.1277 & .33550 & 94 \\
\hline Reduction & 1.1277 & .33550 & 94 \\
\hline
\end{tabular}

\section{Correlations}

\begin{tabular}{|c|c|c|c|}
\hline & & Performance & Reduction \\
\hline \multirow[t]{3}{*}{ Performance } & Pearson Correlation & 1 & $.890^{* *}$ \\
\hline & Sig. (2-tailed) & & .000 \\
\hline & $\mathrm{N}$ & 94 & 94 \\
\hline \multirow[t]{3}{*}{ Reduction } & Pearson Correlation & $.890^{* * *}$ & 1 \\
\hline & Sig. (2-tailed) & .000 & \\
\hline & $\mathrm{N}$ & 94 & 94 \\
\hline
\end{tabular}

**. Correlation is significant at the 0.01 level (2-tailed).

\section{HYPOTHESIS TWO}

DATASET ACTIVATE DataSet1.

DATASET CLOSE DataSet2.

NEW FILE.

DATASET NAME DataSet3 WINDOW=FRONT.

\section{CORRELATIONS}

/VARIABLES=Performance Managerial

$$
\text { /PRINT=TWOTAIL NOSIG }
$$

$/$ MISSING=PAIRWISE.

\section{Correlations}

\begin{tabular}{|c|c|c|c|}
\hline & & Performance & Managerial \\
\hline \multirow[t]{3}{*}{ Performance } & Pearson Correlation & 1 & $.821^{* * *}$ \\
\hline & Sig. (2-tailed) & & .000 \\
\hline & $\mathrm{N}$ & 94 & 86 \\
\hline \multirow[t]{3}{*}{ Managerial } & Pearson Correlation & $.821^{* * *}$ & 1 \\
\hline & Sig. (2-tailed) & .000 & \\
\hline & $\mathrm{N}$ & 86 & 86 \\
\hline
\end{tabular}

**. Correlation is significant at the 0.01 level (2-tailed). 